\title{
Novel Biomarkers in Pancreatic Cancer
}

\author{
Simona O. Dima1 , Cristiana Tanase², Radu Albulescu², \\ Anca Botezatu ${ }^{3}$ and Irinel Popescu ${ }^{1}$ \\ ${ }^{1}$ Center of General Surgery and Liver Transplantation, Fundeni Clinical Institute of \\ Digestive Disease and Liver Transplantation, Bucharest, \\ ${ }^{2}$ Biochemistry and Proteomics Department, \\ "Victor Babes" National Institute of Pathology, Bucharest, \\ ${ }^{3}$ Viral Genetic Engineering Laboratory, \\ Romanian Academy 'Stefan S. Nicolau' Virology Institute, Bucharest, \\ Romania
}

\section{Introduction}

Pancreatic ductal adenocarcinoma( PDAC) cancer is one of the most aggressive human cancers, and the fifth most frequent cause of cancer-related mortality in Western society. Pancreatic cancer is well known for high metastatic potential, early local invasion and poor outcome. The overall 5-year survival rate is less than $5 \%$, respectively $10-30 \%$ for R0 resection (Huang et al., 2010). Less than $10 \%$ of newly diagnosed pancreatic cancers could be detected in early-stage (Takayama et al., 2010).

Clinical research in the field of cancer biomarkers is essential in understanding the biology and the heterogeneity of cancer disease. The factors involved in early PDAC development remain unknown. The detection of pancreatic cancer at early stages, the prediction of the potential resectability, or response to therapy are the current major challenges in improving the clinical outcome of PDAC. Therefore, predictive markers of responsiveness to adjuvant therapy would allow patients selection to appropriate treatment (Duffy et al., 2007). The aim of the postoperative surveillance following curative surgery for PDAC is to detect recurrences or metastases as early as possible.

Currently, there are only few studies that have identified cancer biomarkers with clinical significance.

Molecular biological factors are important tools for early diagnosis, prognosis, not only for therapeutic strategy but also for novel and more efficient therapeutic agents' identification. On the other hand a biomarker must be easily quantified, in order to minimize the invasiveness of therapeutically interventions. Recent finding in the molecular biology field of pancreatic cancer have assisted in translational research, giving hope for individualized therapy and better disease management. 


\section{Identification of new potential tumor tissue biomarkers}

Much effort goes into finding new accurate prognostic, diagnostic single or combined tumor biomarkers. Nowadays, the research in this field is focused not only on finding biomarkers that could discriminate between pathological pancreas conditions (disease related biomarkers), but also to evaluate the aggressiveness grade of PDAC and to determine the therapy response (drug related biomarkers).

Presently, screening for pancreatic cancer is based on state-of-the-art imaging or even invasive diagnostic methods (Balasenthil et al., 2011). Serum and other body fluids, such as urine, pancreatic juice represents sources available by less invasive methods for biomarkers screening.

Several techniques like immunohistochemistry, fluorescence and chromogenic in situ hybridization, expression profiling- performed by microarray or quantitative real-time reverse transcriptase-polymerase chain reaction (qRT-PCR), and mutation analysis are used in identification of new biomarkers. Among these techniques, immunohistochemical tests remain the most widely used in routine practice and, importantly, in the assessment of biomarkers in translational research.

In a recent study, Wacher et. al investigated the expression level of an oncofetal protein, insulin-like growth factor II messenger ribonucleic acid-binding protein 3 (IMP3), which represent a marker for tumor aggressiveness in many different tumors (Wachter et al., 2011; Ozdemir et al., 2011).

The investigation was conducted on tissue biopsies from PDAC, chronic sclerosing pancreatitis, PDAC metastases cases in order to determine IMP3 expression. For IMP3 expression evaluation large tissue sections were used in the immunohistochemical analysis. The results obtained showed that PDAC were positive for IMP3 expression in a high percentage $(88.4 \%)$ of cases, whereas normal or inflammatory pancreatic tissue was weakly positive (23.1\%). A strong IMP3 expression was found in PDAC metastases $(94.4 \%)$. The sensitivity and specificity of IMP3 expression test to discriminate between PDAC and chronic sclerosing pancreatitis using core needle biopsies were found to be $88.4 \%$ and $94.6 \%$, respectively. The authors consider that IMP3 might be an easy to use and potentially new immunohistochemical marker for the diagnosis of PDAC in core needle biopsies (Asioli et al., 2010; Walter et al., 2009).

Another prognostic biomarker in PDAC which characterize the tumor aggressiveness recently studied was vimentin. Vimentin protein is a marker of mesenchymal differentiation, being correlated especially with aggressive carcinomas. In a high percentage primary pancreatic adenocarcinomas contain neoplastic cells that express vimentin, and the presence of this protein was correlated with poor histological differentiation and predicts a shorter postsurgical survival (Li et al., 2009; Handra-Luca et al., 2011).

Several technical strategies (SDS-PAGE, mass spectrometry, immunoblot) are used to find candidate biomarkers for the presurgical management of malignant and premalignant pancreatic conditions. Pancreatic cystic neoplasms represent $10-15 \%$ of primary cystic masses of the pancreas and are detected with an increasing frequency due to the use of advanced imaging modalities in clinical practice. On the other hand, the diagnosis of pancreatic cystic neoplasms remains a challenge because available diagnostic techniques are 
not so specific. The analysis of pancreatic cyst fluids obtained from various cystic lesions showed that specific histological lesions are associated with distinct protein patterns. Two important factors, olfactomedin- 4 (antiapoptotic protein that promotes tumor growth) and mucin-18 (melanoma cell adhesion molecule) were proposed as biomarkers of pancreatic cancer (Cuoghi et al., 2011).

CD99 (cell surface glycoprotein involved in leukocyte migration), a useful diagnostic marker for Ewing sarcoma/primitive neuroectodermal tumor (Rocchi et al., 2010) was proposed for differentiation of solid-pseudopapillary neoplasm from other pancreatic tumor. The tissues positivity for CD99 was investigated in a recent study (Guo et al., 2011) using immunohistochemical staining technique. The solid-pseudopapillary neoplasm cells tumors exhibited paranuclear dot-like immunoreactivity for CD99. In contrast, in pancreatic neuroendocrine tumors a small percent of PDAC stained positive for CD99 at cytoplasmatic and membrane level. Pancreatic solid-pseudopapillary neoplasm exhibits a unique dot-like staining pattern for CD99 and could provide a definitive diagnosis of solid-pseudopapillary neoplasm and differentiation from other pancreatic tumors.

Immunohistochemical analysis of pancreatic cancer tissue provided also several candidate biomarkers for survival estimation. CDCP1 (CUB domain containing protein 1) determines anchorage- independent growth and migration of cancer cells. A higher expression level of this factor is correlated with the overall survival of pancreatic cancer patients (Miyazava et al., 2010). L1-CAM (L1-cell adhesion molecule) expression was also correlated with perineural invasion of pancreatic cancer cells and poor survival (Ben at al., 2010). Higher expression of B7-H3, a co-stimulatory immune molecule, plays a critical role in the T cellmediated immune response and presents a positive correlation with pancreatic cancer prognosis.

KOC (K homology domain containing protein) gene encodes a protein that contains several $\mathrm{KH}$ domains, which are important in RNA binding and are known to be involved in RNA synthesis and metabolism. This protein was found to be overexpressed in pancreatic cancer. Immunohystochemical analysis showed strong staining for KOC protein in invasive pancreatic tissue carcinomas versus normal pancreatic tissue. It was proposed to be a molecular marker with a high sensitivity and specificity in discriminating PDAC from benign ductal epithelium (Toll et al., 2009).

\section{Genome candidate biomarkers}

Most of the adenocarcinomas develop gradually from precursor lesions PanINs (Pancreatic intraepithelial neoplasias). These events are accompanied by genetic modifications. Most genetic abnormalities reported in pancreatic cancer are represented by deletions and duplications of specific chromosomal loci, mutations/deletions of oncogenes and tumorsuppresor genes (KRAS, CDKN1A/p16, TP53, MADH4/SMAD4/DPC4 and BRCA2) [www.cancer-genetics.org].

\subsection{Gene expression studies and potential factors involved in pancreas oncogenesis}

Quantification of target mRNA gene levels represents a new tool for genome function analysis. High-throughput technologies like gene expression profiling using microarray and sequencing become important investigation methods for normal physiological and 
pathological processes. Therefore, studies based on quantification of gene expression levels revealed new potential factors involved in pancreas oncogenesis. Using Affymetrix and cDNA microarrays, nearly 1,100 molecules have been reported to be overexpressed in PanIN and IPMN lesions. A large majority of these molecules showed elevated mRNA levels expression in PDAC and in precursor lesions. Molecules such as S100P, MMP7, MUC4, FSCN1, and MUC5AC are found to be overexpressed in all type of lesions PanIN, IPMN and PDAC (Harsha et al., 2009).

Badea et al. using microarray study identificated a number of genes whose over-expression appears to be inversely correlated with patient survival: keratin 7, laminin gamma 2, stratifin, platelet phosphofructokinase, annexin A2, MAP4K4 and OACT2 (MBOAT2), which are specifically upregulated in the neoplastic epithelium (Badea et al., 2008).

The attention was focused especially on the calcium-binding protein- S100P. This protein was found to be expressed in pancreatic precursor lesions PanIN 2 or PanIN 3 and in pancreatic tumor creating the possibility to use the quantification of its expression level for earlier detection (Dowen et al., 2005). Expression levels of S100P mRNA were found to be higher in pancreatic juice from patients with pancreatic cancer and IPMN (Ohucida et al., 2006). On the other hand, three members of S100A family (S100A2, S100A4, and S100A6) were found to be associated with poor prognostic. S100A family members were involved in cell cycle regulation and cell invasion (Tanase et al., 2010).

The STAT3 transcription factor was found to be constitutively activated in PDAC. This is an important factor in stem cell self-renewal process, cancer cell survival, and inflammation. A close correlation between the levels of tyrosine-phosphorylated STAT3 and of the gp130 receptor was found. An upregulation of the IL6/LIF-gp130 pathway was also showed to be involved in STAT3 activation in pancreatic cancer (Corcoran et al., 2011). The same study asserts that STAT3 is required for the development of the precursor pancreatic lesions, acinar-to-ductal metaplasia (ADM) and PanIN, therefore evaluation of gp130 and phosphoSTAT3 expression may be an effective biomarker.

\subsection{Angiogenesis factors}

With the increasing use of antiangiogenic agents for the treatment of cancers, is necessary the identification of candidate biomarkers for evaluation of the response and resistance. Is also, important to identify new biomarkers and to eliminate the risk for antiangiogenic therapies failure (Duda et al., 2010).

EGF (Epidermal Growth Factor), VEGF (Vascular Endothelial, Growth Factor), heparanase, thrombospondin, cathepsins were the most important angiogenic factor specific for pancreatic cancer involved in cell growth promoting. The overexpression of EGF and his receptor EGFR were linked to tumor staging, but no clear data regarding the overall survival are available at this moment (Heidemann et al.,2006).

Another important factor that acts on angiogenesis process is VEGF. His effects in PDAC are increased by interaction with MMP-9, a cellular matrix remodeling factor. The therapy against both MMP-9 and VEGF in pancreatic cancer resulted in a significant decrease in PDAC growth and microvessel density versus a single target treatment (Tanase-Pistol et al.,2008). 
Heparanases are endoglycosidases that cleave the heparan sulfate side chain of heparan sulfate proteoglycans (major membrane components) inducing extracellular matrix remodelling. On the other hand, heparanase increased growth factor bFGF (fibroblast growth factor) release, stimulating the angiogenesis process (Rohloff et al., 2002)

Thrombospondin (TSP-1) expression level was linked to a good prognostic for PDAC development. TSP-1 protein was found abundantly in stroma surrounding tumor cells and its expression is inversely correlated with microvessel density(Tobita et al., 2002).

The role of cathepsins in pancreatic cancer development and progression is still controversed. Cathepsin b (CTSB) and cathepsin 1 CTSL was found to be overexpressd in PDAC. A correlation between CTSB expression level and perineural invasion concludes the role of cathepsins in local tumor invasion (Niedergethmann et al., 2000).

\subsection{ZIP3 (Zinc/iron regulated transporter-related protein 3) a possible tumor suppressor}

Zinc is the most abundant trace element in cells. For example, about $25 \%$ of the total zinc present is found within the cell nuclei, being a component of chromatin. Zinc is an important factor in cellular processes, including cell division and proliferation, immune function, and defense against free radicals; zinc deficiency may be associated with an increased risk of cancer (Christudoss et al.,2011; Prasad et al., 2002). Zinc is found in over 300 enzymes, including copper/zinc superoxide dismutase, which is an important antioxidant enzyme, involved in cellular protection components from oxidation and damage.

In a current study, Costello et al. found a major loss of zinc in ductal and acinar epithelium in adenocarcinoma compared to the normal epithelium (Costello et al., 2011). The decrease in zinc quantity is a characteristic not only for pancreatic cancer, but also for precursor lesions. The mentioned group showed that the gene expression of ZIP3 (basilar membrane zinc uptake transporter) is present in normal ductal/acinar epithelium and absent in adenocarcinoma. The decreased expression of ZIP3 determines the loss of zinc in early and progressing malignancy. RREB1 transcription factor was found to be down regulated along with ZIP3 and might be the silencing cause of ZIP3 gene. Zinc treatment exhibited cytotoxic effect on Panc1 cell line. ZIP3 and RREB-1 expression level changes represent early events in the development of adenocarcinoma suggesting that ZIP3 might be a tumor suppressor gene.

\subsection{Other important factors}

FAP (fibroblast activation protein) is involved in the control of fibroblast growth or epithelial-mesenchymal interactions during development, tissue repair, and epithelial carcinogenesis. It is highly expressed in PDAC and is considered to be related to a poor prognostic. Targeting FAP factors are considered to be a promising and a new therapeuthical road (Cohen et al., 2008).

Maspin (SerpinB5- mammary serine protease inhibitor) is a tumor suppressor gene. Maspin induces apoptosis in neoplastic cells and expression of maspin are suppressed as the carcinoma progresses in breast and prostatic carcinoma (Jiang et al., 2002). The pattern of maspin gene expression is dependent of the disease stage. For example, highly expression 
was observed in intraductal papillary mucinous neoplasms, mucinous cystic neoplasms. and in carcinomas, whereas in adenomas is lower.It was also observed a significant decrease in maspin expression when intraductal papillary mucinous neoplasms progresses to invasion. However, the group with high maspin expression presented microinvasion, whereas low expression maspin group showed extensive invasion (Kashima et al., 2008). These results conclude that maspine could be a good prognostic factor for invasion.

\section{Cancer stem cell biomarkers}

Stem cell markers are a promising group of new biomarkers. Solid tumors contain small proportions of cells that are capable of proliferation, self-renewal, and differentiation into various cell types. These types of cells (cancer stem cells) are characterized by treatment resistance, especially to ionizing radiation. Therefore, it is a very challenging situation in order to identify these cells, to understand the mechanisms of resistance, and to evaluate the patient therapy outcome regarding the response to treatment. Identifying the markers that characterize cancer stem cells is the main research and a specific pattern regarding cell surface markers is emerging. In breast cancer, stem cells presented a characteristic antigenic pattern, whereas in high-grade gliomas, expression of CD133 on the cell surface selects a population of treatment resistant cells (Woodward \& Sulman, 2008).

In pancreatic cancer, several surface markers have been identified for a subpopulation of the tumor cells with stem cell characteristics. These cancer stem cells were identified by expression of the cell surface markers CD44, CD24, and ESA (Li et al., 2007). When injected in the pancreas of immunocompromised mice these human cells are able to self-renew and generate differentiated progeny, to recapitulate the phenotype of the tumor from which they were derived.

Another subpopulation of cancer stem cells highly tumorigenic was isolated from patients with PDAC. These cell types were CD133+ and were able to induce tumor formation in athymic mice. This subpopulation of migrating cancer stem cells are characterized also by expression of the CXCR4 receptor and are involved in tumor metastasis Hermann et al., 2007.

Another candidate cell marker investigated was aldehyde dehydrogenase 1A1 (ALDH1A1), which has been identified to label cancer stem cells in breast cancer (Ginestier et al., 2007), colon cancer (Huang et al., 2009), lung cancer (Jiang et al., 2009) and head and neck squamous cancer (Chen et al., 2009). ALDH1 is a member of the aldehyde dehydrogenase gene (ALDH) superfamily playing an important role in the metabolism of endogenous and exogenous aldehydes. This $\mathrm{NAD}(\mathrm{P})(+)$-dependent enzyme is also involved in the formation of molecules that are important in cellular processes, like retinoic acid (acting like modulator of gene regulation and cell differentiation), betaine and gamma-aminobutyric acid and exhibits additional, non-enzymatic functions, being able to bind to some hormones (Yoshida et al., 1998). The ALDH1 gene expression is ubiquitous in many human tissues; the protein is found localized mainly in the cellular cytoplasm.

It was also shown that ALDH1 has the capacity to detoxify aldophosphamide, conferring chemoresistance against cyclophosphamide to overexpressing cell (Hilton, 1984). Data regarding the effect of ALDH1A1 overexpression are controversial. Increased expression of 
ALDH1 in ovarian cancer correlates with a favourable prognostic. In contrast, pancreatic cancer increased expression of ALDH1A1 was correlated with poor survival (Rasheed et al., 2010).

ALDH1+ breast tumors are negative for estrogen receptor and progesterone receptor overexpression, but present a high level of Ki67 expression (a nuclear protein that is associated with cellular proliferation) (Morimoto et al., 2009). Therefore, Kahlert et al. showed that a high expression of ALDH1A1 is significantly correlated with the proliferation rate of pancreatic tumour cells (Kahlert et al., 2011).

\section{Drug-related biomarkers}

Most of the pancreatic cancer patients have inoperable disease due to distant metastases or locally advanced tumor and the main therapeutic decision in this case is systemic chemotherapy or chemoradiation. Therefore, understanding the mechanisms that govern drug-related resistance and the factors involved in this process are a mandatory condition for therapeutic management success.

\subsection{Metabolic prognosis factors for gemcitabine resistance}

Patients with advanced or metastatic pancreatic cancer are treated with gemcitabine as a first line chemotherapeutic agent. Gemcitabine is a 2',2'-difluoro-2-deoxycytidine analogue that inhibits DNA replication and repair. Gemcitabine possesses radiosensitizing properties and its administration must be combined with radiotherapy. The sensitivity to gemcitabine and its efficiency were correlated with several factors. One of the factors that correlate with gemcitabine sensitivity is hENT1 (human equilibrative nucleoside transporter 1) (Nakano et al., 2007).

Pancreatic cancer cells that highly express hENT1 are sensitive to gemcitabine by uptaking this therapeutic agent in cancer cells. The absence hENT1 expression in metastatic pancreatic adenocarcinoma pacients treated with gemcitabine was associated with a poor prognostic compared with patients whom tumor cancer cells presented hENT1 expression (Hamada \& Shimosegawa, 2011).

At the cellular level, gemcitabine is phosphorylated to its active metabolites by dCK (deoxycytidine kinase). Another group reported that not only hENT1 higher expression is a possible prognostic factor, but also dCK expression level and its activity correlates with gemcitabine activity (Ashida et al., 2009). High dCK enzyme activity was linked with gemcitabine sensitivity in experimental models (Kroep et al., 2002) and biopsy samples analysis (Sebastiani et al., 2006).

Gemcitabine inactivation is performed through an enzymatic deamination process. There are three important enzymes involved in gemcitabine deamination (deoxycytidylate deaminase-DCD, cytidine deaminase-CDA and 5'-nucleotidase -5'-NT). The increased activity of such enzymes could induce the resistance to gemcitabine (Kroep et al., 2002; Giovannetti et al., 2006; Nakano et al., 2007) Gemcitabine resistance mechanism is also realized by high expression of RRM1 and RRM2, which are the two subunits (large and small) of ribonucleotide reductase. This enzyme regulates the rate of DNA synthesis, and is also known to convert ribonucleotides to deoxyribonucleotides. Gemcitabine exerts its 
cytotoxicity by inhibiting ribonucleotide reductase (Davidson et al., 2004; Bergman et al., 2005; Nakahira et al., 2006)

\section{Epigenetic biomarkers}

Cancer initiation and progression is traditionally characterized as a genetic alteration, but recent years crystallized in a new direction regarding epigenetic mechanisms involvement in oncogenesis. Epigenetic mechanisms are essential for normal development and for maintaining of a tissue specific pattern of gene expression. Epigenetic modifications lead to an abnormal genetic expression and further to malign transformation. The research in epigenetic field has demonstrated the involvement of an intensive reprogramming of epigenetic machinery (DNA methylation, histone modifications, microRNA expression). The reverse nature of epigenetic abnormalities permitted the development of epigenetic therapy field.

\subsection{Gene promoter methylation status and pancreatic oncogenesis}

The most known epigenetic modification in oncogenesis is DNA hypermethylation. This event is accompanied by genetic silencing. Identification and characterization of epigenetically silenced genes is important in order to understand the roles of such epigenetic modification in oncogenesis and to discover new tumor markers. It was reported that in pancreas cancer some tumor suppressor genes presented aberrant CpG islands hypermethylation at gene promoter level.

The first tumor suppressor gene identified to be specific for pancreatic cancer was p16/CDKN1A (Schutte et al., 1997). Subsequently, new hypermethylated genes were associated with pancreatic cancer (hMLH1, E-cadherin, ppENK, CDKN1C, SPARC, TFPI-2, GATA4,5, BNIP3, TSLC1, HHIP, MUC2, reprimo, CXCR4 si SOCS1) (Omura et al., 2009).

Several important epigenetically silenced factors have been identified (hsa-miR-9-1, ZNF415, CNTNAP2 si ELOVL4) (Omura et al 2009; Grady et al.,2008; Lehmann et al,.2008; Fabbri et al., 2007; Moriss et al., 2004).

Using methylated $\mathrm{CpG}$ island amplification (MCA) and representational difference analysis (RDA), Ueki et al group identified that gene preproenkephalin ( $p p E N K)$ presented a hypermethylated promoter in most pancreatic cancers (Ueki et al., 2001). ppENK encodes an opioid peptide which presents growth-suppressor properties.

It was showed that CDKN1C/p57KIP2 gene presented a decrease expression in intraductal papillary mucinous neoplasm. The gene encodes for cyclin-dependent kinase inhibitor, and is a negative regulator of cell proliferation (Sato et al., 2005). Partial methylation of the CDKN1C promoter was found in pancreatic cancer cell lines and pancreas cancer.

SPARC (secreted protein acidic and rich in cysteine, or osteonectin/BM40) is a matrixassociated protein; calcium binding, that inhibits cell-cycle progression, and influences the synthesis of extracellular matrix. The gene codifying this protein was found aberrantly methylated in pancreatic cancer by. SPARC is a factor involved in many processes like cell migration, proliferation, matrix cell adhesion (Sato et al., 2003, Gao et al., 2010).

Tissue factor pathway inhibitor 2 (TFPI-2) is a Kunitz-type serine proteinase inhibitor, which has been identified as a putative tumor-suppressor gene. Aberrant methylation of TFPI-2 
was found in pancreatic cancer xenografts and primary pancreatic adenocarcinomas. Reexpression of the TFPI-2 gene led in the proliferation, migration and invasion of cancer cells (Sato et al., 2005).

GATA gene family members were also epigenetic silenced in pancreatic cancer. For example, GATA-5 was frequently methylated in pancreatic cancers, whereas GATA-4 was hypomethylated (Fu et al., 2007).

Another gene commonly silenced epigenetically in pancreatic cancer is BNIP3. The protein encoded by this gene contains a $\mathrm{BH} 3$ domain and a transmembrane domain associated with pro-apoptotic function. BNIP3 gene silencing induced a drug resistance mechanism in pancreatic cancer cells, as a potential drug resistance mechanism (Okami et al., 2004)

Shimizu et al. using a novel method called "microarray coupled with methyl-CpG targeted transcriptional activation" (MeTA-array for short), identified 16 genes hypermethylated in three representative pancreatic cancer cell lines, AsPC-1, MIA PaCa-2 and PANC-1. Among these 16 genes several presented higher methylation level (CSMD2, SLC32A1, TMEM204 and TRH). CSMD2, SLC32A1 and TRH genes presented also a hypermethylated pattern in primary pancreatic cancers (Shimizu et al., 2011).

In contrast, a great number of genes are overexpressed in pancreatic cancer. These genes presented hypomethylation of the promoter in pancreatic cancer versus normal pancreatic tissue.

DNA hypomethylation of promoter CpGs were identified in genes with overexpression pattern including claudin4, lipocalin2, 14-3-3sigma/ stratifin, trefoil factor 2, S100A4, mesothelin, PSCA, S100P and maspin (Sato et al., 2003).

\subsection{Histone modifications hallmarks for oncogenesis process}

Covalent histone modifications are important regulatory elements in many biological processes. These modifications control the chromatin status by electrostatic interaction changes and non-histonic protein recruitement. Histones suffer specific N-terminal end post-translational changes represented by acethylation, methylation, phosphorylation, sumoylation, ubiquitination and ADP-ribosylation. These modifications alter DNA-histones interaction having a major impact on chromatin structure (Strahl et al., 2000).

Certain histone modifications influence gene transcription level. The interplay between histone modifications led to 'histone code hypothesis'. For example, lysine acetylation neutralizes the charge between DNA and histone tails and correlates with a more transcription permissive status of chromatin (Jenuwein et al., 2001).

Hypermethylated CpG islands of silenced tumor-suppressor genes are correlated with deacetylation of histones $\mathrm{H} 3$ and $\mathrm{H} 4$, methylation of $\mathrm{H} 3$ lysine 9 (H3K9), H3 lysine 27 (H3K27), and H4 lysine 20 (H4K20), and demethylation of H3 lysine 4 (Rosenfeld et al., 2009; Barski et al., 2007). Methylation of histone H3 lysine 4 (H3K4) and H3 lysine 36 is associated with relaxed chromatin status (Benevolenskaya et al., 2007). Histone modifications recruit effector proteins. Acetylated lysines are recognized by bromodomains within nucleosome remodeling complexes, methylated $\mathrm{H} 3 \mathrm{~K} 4$ and the helicase Chd1 chromodomain recruits activating complexes of chromatin (Daniel et al., 2005). In contrast, methylated H3K9 and 
H3K27 interacts with heterochromatin protein 1 (HP 1) and Polycomb-group (PcG) proteins leading to chromatin compaction (Fischle et al., 2003). PcG proteins function as transcriptional repressors, but the molecular mechanisms of Polycomb repressive complex (PRC)-mediated repression is not clear (Sparmann et al., 2006). PcG proteins recruits DNMTs (DNA methyl transferase) involved in the hypermethylation of tumor suppressor genes (Vire et al., 2006).

Only few studies have examined genes that are regulated by histone modifications in pancreatic cancers. For example, mucin family gene underwent histone alterations in pancreatic cancers in association with gene overexpression. The $5^{\prime}$ region of MUC1 gene transcriptional start site is enriched in tri/dimethylated $\mathrm{H} 3 \mathrm{~K} 9$ and methylated DNA in nontumor cells (Yamada et al., 2008). Transcriptional start site of MUC2 is highly enriched in diand tri-methylated $\mathrm{H} 3 \mathrm{~K} 4$, acetylated $\mathrm{H} 3 \mathrm{~K} 9$, and acetylated $\mathrm{H} 3 \mathrm{~K} 27$ in pancreatic cancer cells. Vincent et al demonstrated that MUC4 transcription activity is affected by many factors (DNMT3A, DNMT3B, HDAC1 and HDAC3, DNA methylation, histone modification (Vincent et al., 2008).

\section{Model organisms studies provide potential biomarkers in pancreas oncogenesis}

Model organisms are widely used to explore potential causes and treatments for human disease. This strategy is made possible by the conservation of metabolic and developmental pathways and genetic material over the course of evolution.

It is known that Enolase 1 (a-enolase or non-neuronal enolase -NNE), is an isoenzyme of enolase, which catalyze the conversion of 2-phosphoglycerate into phosphoenolpyruvate.

Several studies have shown that enolase 1 plays an important role in in tumorigenesis, cancer invasion and metastasis. Proteomic studies reported that expression of enolase 1 is increased in cancers, such as hepatocellular carcinoma (Takashima et al. 2008, Hamaguchi et al., 2008) , non-small lung cancer (He et al., 2007), esophageal adenocarcinoma (Zhao et al., 2007), prostate cancer (van den Bemd et al., 2006), colon cancer (Katayama et al., 2006), oral epithelial and squamous cell carcinoma (Ito et al., 2007).

In pancreatic cancer Mikuriya et al using two-dimensional electrophoresis and liquid chromatography-mass spectrometry/mass spectrometry showed that the expression levels of glycolytic enzymes, including enolase 1, increased in the cancerous pancreatic tissues patients compared with the paired non-cancerous tissues (Mikuriya et al., 2007).

In order to evaluate Enolase 1 expression changes, Lei et al. used chemical induced carcinogenesis in rats. Implantation of 7,12-dimethylbenzanthracene in rat pancreas leads to pancreatic cancer and PanINs. Alpha-enolase was specifically overexpressed in tumors compared with normal and pancreatic tissues (Lei et al., 2011).

The group found several proteins overexpressed in this carcinogenesis model, along with enolase 1 (Tumor protein translationally controlled 1, Expressed in non-metastatic cells 2, Pancreatic elastase 3B, Necdin, Hbp23, Chromodomain helicase DNA-binding protein, Albumin+retinoid $X$ receptor-interacting protein, Heterogeneous nuclear ribonucleoprotein A2/B1-hnRNP A2/B1). 
The hnRNP A2/B1 protein plays an important role in the biogenesis and transport of mRNA. Abnormal expression of this protein leads to alteration of normal transcription. In concordance with this study a previous work found high levels of hnRNP A2/B1 expression in a limited number of human pancreatic adenocarcinomas from smokers and two pancreatic tumor cell lines, HPAF-11 and SU 86 (Shen et al., 2004). In contrast, carboxyl ester lipase (CEL pancreatic exocrine enzyme) expression level progressively decreased with DMBA-induced disease severity.

DMBA implantation into the rat pancreas is an effective method to induce PanINs and pancreas cancer in order to determine which the first change in proteins expression pattern is, and to identify markers for pancreas lesions progression.

\section{Novel biomarkers for the non-invasive diagnosis of pancreatic cancer}

Actually, diagnostic methods for pancreatic cancer include invasive procedures (tissue sampling by endoscopy), involving risks and causing complications. The necessity for less invasive diagnostic methods is increasing; therefore the development of non-invasive biomarkers in pancreatic cancer is mandatory.

\subsection{Plasma biomarkers}

The major directions of proteomic range from basic research to discovery, validation and use of clinical applications. Protein profiling methods include high resolution twodimensional gels, two-dimensional differential in-gel electrophoresis, LC-MS and LCMS/MS using accurate mass tags, and protein identifications using mass spectrometry methods. These methods were used in many studies for identification of prognostic and/or predictive biomarkers that may help stratify patients.

The only clinically available serum biomarker for PDAC is CA 19-9, which is useful for the follow-up of pancreatic cancer patients receiving treatment, but has not been recommended for cancer screening (Goggins et al., 2000; Locker et al., 2006). The American Society of Clinical Oncology (ASCO) 2006 guidelines for the use of tumor markers do not recommend CA19-9 as a screening test for pancreatic cancer (Rosty et al., 2002; Liang et al., 2009). Several other serum markers have been proposed for pancreatic cancer.

Recent papers published new promising biomarkers, which can potentially detect early stage pancreatic cancer (Chen et al., 2011).

Roberts et al. analyzed serum samples from patients with locally advanced or metastatic adenocarcinoma of the pancreas. Patient group was selected based on length of survival and type of therapy, and serum was subjected to liquid chromatography coupled to tandem mass spectrometry analysis (LC-MS-MS) (Roberts et al., 2011). The proteins presenting important changes in expression levels were validated by enzyme-linked immunosorbent assay (ELISA). After the data were analyzed, the authors selected 1 putative prognostic protein, alpha 1antichymotrypsin (AACT), and 2 putative predictive proteins, histidine-rich glycoprotein (HRG) and complement factor $\mathrm{H}(\mathrm{CFH})$. AACT was found to be negatively correlated with overall survival, whereas $\mathrm{CFH}$ was found to have no predictive value as prognostic factor for overall survival. AACT may be a useful prognostic marker in patients with advanced stage pancreatic carcinoma, although additional validation studies are needed. 
Another study involving quantification in patient serum of tumor cell metabolites, or secreted factor was conducted by He et al. . This study focused on DJ-1 oncoprotein secreted by cancer cells (He et al., 2011). The study group involved patients diagnosed with pancreatic cancer and chronic pancreatitis, along with healthy subjects. DJ-1 serum level and the conventional tumor marker carbohydrate antigen 19-9 (CA 19-9) were measured in order to establish the diagnostic and prognostic value of DJ-1. Serum DJ-1 level was increased in patients with pancreas cancer compared with chronic pancreatitis and healthy individuals. Serum DJ-1 levels were higher than CA 19-9, and combined the two biomarkers provided a sensitivity of $87.5 \%$. After resection DJ-1 levels decreased and patient with lower value of this factor had a better prognosis. This study provides a potential clinical biomarker, easy to quantify from serum, in order to establish a rapid diagnosis and to evaluate prognosis in patients with pancreas cancer.

\subsection{Pancreatic juice biomarkers}

Analysis of protein expression profiles of pancreatic juice samples harvested from the pancreatic duct has the potential to identify markers that could serve for diagnosis triage of benign from malignant pancreatic lesions and to discriminate between different stages of PDAC.

The research performed by Vareed et al. has shown that 56 proteins were found to be elevated in pancreatic juice of PDAC patients compared to benign controls (Vareed et al., 2011).

Protein profiles studies revealed an unique presence of proteins associated with Parkinson's disease namely: aSyn and PARK7 (Bonifati et al., 2003; Singleton et al., 2003).

Increased expression of aSyn has been also identified in melanoma (Matsuo et al., 2010), while its isoform gamma-synuclein (cSyn) has been shown to be elevated in tumors of breast, uterine, colorectal and pancreas (Ye et al., 2009; Hibi et al., 2009; Ahmad et al., 2007; Li et al., 2004; Gupta et al., 2003; Jia et al., 1999; Morgan et al., 2009). Moreover, due to the structural omology between cSyn and aSyn, these factors potentiate invasion in these tumors.

Interestingly, tissue arrays demonstrated a strong staining for aSyn in tumors, and this protein expressed in a subset of PDAC patients was identified in its aggregated form similar to Lewy Bodies seen in Parkinson's disease (Polymeropoulus et al., 1997). Another interesting coincidence is the presence of increased levels of Parkinson's disease associated protein PARK7 (DJ1) (van Duijin et al., 2001) in pancreatic ductal juice of adenocarcinomas. The mechanism by which the protein PARK-7 exerts its oncogenic effect remains unclear. It is presumed the involvement of p38 mitogen activated-protein kinase signaling (Mo et al., 2010).

On the other hand PDAC-associated secretory proteome analysis also revealed increased levels of several metabolic enzymes. The most important metabolic factor was Purine NucleosidePhosphorylase (NP), enzyme involved in salvage pathway of purines, which is operational during inflammation and neoplastic progression, (Bantia et al., 2010). NP activity has been reported to be high in cancer sera (Roberts et al., 2004) and NP expression has also been used to determine the clinical severity of various types of cancers, in combination with another factor adenosine deaminase (ADA) (Mesarosova et al., 1993). 
This strong association between NP with inflammation determined to evaluate the expression and activity of this protein in PDAC, specifically in patients with antecedent inflammatory conditions like chronic pancreatitis, and pancreatic intraepithelial neoplasia (PanIN) (Rebours et al., 2010). Therefore, this correlation makes NP levels quantification to be a useful marker for surveillance progression from inflammation to PDAC.

\subsection{Saliva biomarkers}

Saliva is a body fluid that can be easily obtained without using a special technique. Recent reports suggested the possible utility of saliva in quantification of specific factors to discriminate between pancreatic cancer patients and patients with normal or chronic pancreatitis.

Using transcriptome profiles, Zhang et al. group could differentiate pancreatic cancer patients from healthy subject with a sensitivity of $90.0 \%$ and a specificity of $95.0 \%$. The group found 12 mRNA biomarkers specific for pancreatic cancer patients. Seven genes were found to be up-regulated (MBD3L2, KRAS, STIM2, DMXL2ACRV1, DMD, CABLES1), whereas five genes presented a decreased expression TK2, GLTSCR2, CDKL3, DPM1, TPT1 (Zhang et al., 2010).

A similar approach has been made by another group, which evaluated metabolites in saliva using mass spectrometry. Pancreatic cancer cases were successfully detected based on the pancreatic cancer-specific signature (Sugimoto et al., 2010). The levels of ornithine and putrescine were higher in patients with breast or pancreatic cancer, and were markedly higher in patients with oral cancer. The level of tryptophan is also increased in oral and pancreatic cancer, in contrast to arginine level which is decreased several cancers including breast, colonic and pancreatic cancer, which might be due to increased uptake of arginine by tumor tissues with high arginase activity.

\subsection{Non- coding RNA as new era biomarkers}

A new and important atractive tool is represented by small non-coding RNA. These are regulators of various biological processes like gene expression and are involved in cancer progression. One of the most important players is microRNAs which control many cellular functions, such as migration, invasion and stem cell functions. Abnormal microRNA gene expression was found in many cancers, including pancreatic cancer (Rachangani et al., 2010, Eis et al., 2005, Calin et al., 2005, Yanaihara et al., 2006).

MicroRNA molecules are present in various body fluids (blood, urine, cerebrospinal fluid, pancreatic juice, billiary secretion). Moreover, several microRNAs from sera seemed to be identical for many cancer types. Very important is the fact that miRNAs from sera are stable and exhibit resistance to $\mathrm{RN}$-ase activity, intermittent frosting and defrosting, high temperature values and extreme pH ( Mitchell et al., 2008; Albulescu et al., 2011).

Using microarray technology it was established that several microRNAs are highly expressed in pancreatic cancer (miR-21, miR-17-5p,miR-191,miR-29b-2,miR-223 miR-128b, miR-199a-1, miR-24-1, miR-24-2,miR-146, miR-181b-1, miR-20a,miR-107,miR-32 , miR-92-2, miR-214,miR-30c, miR-25, miR-221, miR-106) (Volinia et al., 2006). More recently, was established that microRNAs, miR-200a and miR-200b are highly expressed in pancreatic 
cancer cell lines, and their expression levels were significantly increased in the sera from pancreatic cancer patients, suggesting that microRNA itself could be a biomarker for pancreatic cancer (Li et al., 2010). The attention was also focused on two pancreas specific miRNAs miR-216 and miR-217. The expression of those miRNAs is decreased or even absent in PADC and in cell lines (Sood et al., 2006). Only miR-217 and miR-196a are able to discriminate between normal pancreas, chronic pancreatitis and tumor PDAC (Szafranska et al., 2008). Furthermore, miR-196a expression is likely specific to PDAC cells and is positively associated with the progression of PDAC.

miR-21 and miR-155 are overexpressed in pancreatic tumor, as compared to tissues from normal pancreas and chronic pancreatitis. Both miR-21 and miR-155 have been suggested to have a proto-oncogene role being overexpressed in several cancers (breast cancer, lung cancer, Burkitt lymphoma, B-cell lymphoma) (Metzler et al., 2004;Yin et al., 2008)

Several studies demonstrated that miR-155 transcription is regulated by transforming growthfactor $\beta$-TGF $\beta /$ Smad, nuclear factor- $\mathrm{kB}$ and activator protein- 1 family transcription factors through direct interaction with the miR-155/BIC bidirectional promoter. These studies suggests that overexpression of miR-155 in cancer is due to transcriptional activation, involving other cellular deregulated mechanisms (Kong et al., 2008).

\section{Conclusions}

Asymptomatic pancreatic cancer is hard to detect, but possibly curable. Recent research identified novel biomarkers of pancreatic cancer, but screening for early pancreatic cancer is still challenging. Future work should be addressed to the development of diagnostic techniques with a higher sensitivity to detect even asymptomatic cases. Currently no clinically useful interventions to screen for patients with PDAC are available.

\section{Acknowledgements}

The authors are grateful for the funding support offered by POSDRU/89/1.5/S/60746 Grant.

\section{References}

Ahmad, M., Attoub, S., Singh, M.N., Martin, F.L. \& El-Agnaf, O.M. (2007). Gammasynuclein and the progression of cancer. FASEB J, 21: 3419-3430.

Albulescu, R., Tănase, C. \& Neagu, M. (2011). Tissular and soluble microRNAs for diagnostic improvement and therapy in digestive tract cancers. Expert Review of Molecular Diagnostics, 11(1): 101-120.

Ashida, R., Nakata, B., Shigekawa, M., Mizuno, N., Sawaki, A., Hirakawa, K., Arakawa, T., Yamao, K. (2009) Gemcitabine sensitivity-related mRNA expression in endoscopic ultrasound-guided fine-needle aspiration biopsy of unresectable pancreatic cancer. J Exp Clin Cancer Re, 28: 83.

Asioli, S., Erickson, L.A., Righi, A., Jin, L., Volante, M., Jenkins, S., Papotti, M., Bussolati, G. \& Lloyd, R.V. (2010). Poorly differentiated carcinoma of the thyroid: validation of the Turin proposal and analysis of IMP3 expression. Mod Pathol., 23(9):1269-78. 
Badea, L., Herlea, V., Dima, S.O., Dumitrascu, T. \& Popescu, I. (2008) Combined gene expression analysis of whole-tissue and microdissected pancreatic ductal adenocarcinoma identifies genes specifically overexpressed in tumor epithelia, 55(88):2016-27.

Balasenthil, S., Chen, N. \& Lott, S.T. (2011) A migration signature and plasma biomarker panel for pancreatic adenocarcinoma. Cancer Prev Res (Phila), 4:137-149.

Bantia, S., Parker, C., Upshaw, R., Cunningham, A. \& Kotian P.(2010). Potent orally bioavailable purine nucleoside phosphorylase inhibitor BCX-4208 induces apoptosis in B- and T-lymphocytes-a novel treatment approach for autoimmune diseases, organ transplantation and hematologic malignancies. Int Immunopharmacol., 10(7):784-90.

Barski, A., Cuddapah, S., Cui, K., Roh, T.Y., Schones, D.E., Wang, Z., Wei, G., Chepelev, I. \& Zhao, K. (2007). High-resolution profiling of histone methylations in the human genome". Cell, 129(4): 823-37.

Beer, D.G., Lubman, D.M. (2007). Comparative proteomics analysis of Barrett metaplasia and esophageal adenocarcinoma using two-dimensional liquid mass mapping. $\mathrm{Mol}$ Cell Proteomics, 6, 987-999

Ben, Q.W., Wang, J.C., Liu, J., Zhu, Y., Yuan, F., Yao, W.Y. \& Yuan, Y.Z. (2010) Positive expression of L1-CAM is associated with perineural invasion and poor outcome in pancreatic ductal adenocarcinoma. Ann Surg Oncol, 17: 2213-2221.

Benevolenskaya, E.V. (2007). Histone H3K4 demethylases are essential in development and differentiation. Biochem. Cell Biol., 85 (4): 435-43.

Bergman, A.M., Eijk, P.P., Ruiz van Haperen, V.W., Smid, K., Veerman, G., Hubeek, I., van den Ijssel, P., Ylstra, B. \& Peters, G.J. (2005) In vivo induction of resistance to gemcitabine results in increased expression of ribonucleotide reductase subunit M1 as the major determinant. Cancer Res, 65:9510-9516.

Bonifati, V., Rizzu, P., Squitieri, F., Krieger, E. \& Vanacore, N. (2003). DJ-1(PARK7), a novel gene for autosomal recessive, early onset parkinsonism.Neurol Sci, 24: 159-160.

Calin, G.A., Querzoli, P., Negrini, M. \& Croce, C.M. (2005). MicroRNA gene expression deregulation in human breast cancer. CancerRes; 65: 7065-7070.

Chen, Y.C., Bunger, S., Laubert, T., Roblick, U.J. \& Habermann, J.K. (2011). Serum biomarkers for improved diagnostic of pancreatic cancer: a current overview. J Cancer Res Clin Oncol; 137:375-389.

Chen, Y.W., Hsu, H.S., Tseng, L.M., Huang, P.I., Lu, K.H., Chen, D.T., Tai, L.K., Yung, M.C., Chang, B., Liu, G., Xue, F., Rosen, D.G., Xiao, L., Wang, X. \& Liu, J. (2009) ALDH1 expression correlates with favorable prognosis in ovarian cancers. Mod Pathol, 22(6):817-823.

Christudoss, P., Selvakumar, R., Fleming, J.J. \& Gopalakrishnan, G. (2011) Zinc status of patients with benign prostatic hyperplasia and prostate carcinoma. Indian J Urol, 27(1):14-8.

Cohen, S.J., Alpaugh, R.K., Palazzo, I., Meropol, N.J., Rogatko, A. \& Xu Z. (2008) Fibroblast activation protein and its relationship to clinical outcome in pancreatic adenocarcinoma. Pancreas, 37(2):154-158.

Corcoran, R.B., Contino, G., Deshpande, V., Tzatsos, A., Conrad, C., Benes, C.H., Levy, D.E., Settleman, J., Engelman, J.A. \& Bardeesy, N. (2011) STAT3 Plays a Critical Role in KRAS-Induced Pancreatic Tumorigenesis. Cancer Res; 71(14): 1-10. 
Costello, L.C., Levy, B.A., Desouki, M.M., Zou, J., Bagasra, O., Johnson, L.A., Hanna, N.\& Franklin, R.B. (2011). Decreased zinc and down regulation of ZIP3 zinc uptake transporter in the development of pancreatic adenocarcinoma. Cancer Biol Ther. 12(4).

Cuoghi, A., Farina, A., Z'graggen, K., Dumonceau, J.M., Tomasi, A., Hochstrasser, D.F., Genevay, M., Lescuyer, P. \& Frossard, J.L. (2011) Role of proteomics to differentiate between benign and potentially malignant pancreatic cysts. J Proteome Res, 10(5):2664-70.

Daniel, J.A., Pray-Grant, M.G., Grant, P.A. (2005) Effector proteins for methylated histones: an expanding family. Cell Cycle, 4:919-926.

Davidson, J.D., Ma, L., Flagella, M., Geeganage, S., Gelbert, L.M. \& Slapak, C.A. (2004) An increase in the expression of ribonucleotide reductase large subunit 1 is associated with gemcitabine resistance in non-small cell lung cancer cell lines. Cancer Res, 64:3761-3766.

Dowen, S.E., Crnogorac-Jurcevic, T., Gangeswaran, R., Hansen, M., Eloranta, J.J., Bhakta, V., Brentnall, T.A., Luttges, J., Kloppel, G. \& Lemoine, N.R. (2005) Expression of S100P and its novel binding partner S100PBPR in early pancreatic cancer. Am J Pathol, 166: 81-92.

Duda, D.G., Ancukiewicz, M. \& Rakesh, K. (2010) Jain Biomarkers of Antiangiogenic Therapy: How Do We Move From Candidate Biomarkers to Valid Biomarkers? JCO, 28(2): 183-185.

Duffy, MJ. 2007 Role of tumor markers in patients with solid cancers: A critical review. Eur J Intern Med, 18:175-184.

Eis, P.S., Tam, W., Sun, L., Chadburn, A., Li, Z., Gomez, M.F., Lund, E., \& Dahlberg, J.E. (2005). Accumulation of miR-155 and BIC RNA in human B cell lymphomas. Proc Natl Acad Sci USA ,102:3627-3632.

Fabbri, M., Garzon, R., Cimmino, A., Liu, Z., Zanesi, N., Callegari, E., Liu, S., Alder, H., Costinean, S., Fernandez-Cymering, C., Volinia, S., Guler, G., Morrison, C.D., Chan, K.K., Marcucci, G., Calin, G.A., Huebner, K., \& Croce, C.M. (2007). MicroRNA-29 family reverts aberrant methylation in lung cancer by targeting DNA methyltransferases 3A and 3B. Proc Natl Acad Sci USA, 104: 15805-15810.

Fischle, W., Wang, Y., Jacobs, S.A., Kim, Y., Allis, C.D.\& Khorasanizadeh, S.( 2003) Molecular basis for the discrimination of repressive methyl-lysine marks in histone H3 by Polycomb and HP1 chromodomains. Genes Dev, 17:1870-1881.

Fu, B., Guo, M., Wang, S., Campagna, D., Luo, M., Herman, J.G.\& Iacobuzio-Donahue, C.A. (2007). Evaluation of GATA-4 and GATA-5 methylation profiles in human pancreatic cancers indicate promoter methylation patterns distinct from other human tumor types. Cancer Biol Ther., 6(10):1546-52.

Gao, J., Song, J., Huang, H., Li, Z., Du, Y., Cao, J., Li, M., Lv, S., Lin, H. \& Gong, Y. (2010). Methylation of the SPARC gene promoter and its clinical implication in pancreatic cancer. J Exp Clin Cancer Res., 26;29:28.

Ginestier, C., Hur, M.H., Charafe-Jauffret, E., Monville, F., Dutcher, J., Brown, M., Jacquemier, J., Viens, P., Kleer, C.G., Liu, S., et al. (2007). ALDH1 is a marker of normal and malignant human mammary stem cells and a predictor of poorclinical outcome. Cell Stem Cell , 1(5):555-567. 
Giovannetti, E., Del Tacca, M., Mey, V., Funel, N., Nannizzi, S., Ricci, S, Orlandini, C., Boggi, U., Campani, D., Del Chiaro, M., Iannopollo, M., Bevilacqua, G., Mosca, F. \& Danesi, R. (2006). Transcription analysis of human equilibrative nucleoside transpoter-1 predicts survival in pancreas cancer patients treated with gemcitabine. Cancer Res , 66:3928-3935.

Goggins, M., Canto, M. \& Hruban, R. (2000) Can we screen high-risk individuals to detect early pancreatic carcinoma? J Surg Oncol, 74:243-248.

Grady, W.M., Parkin, R.K., Mitchell, P.S., Lee, J.H., Kim, Y.H., Tsuchiya, K.D., Washington, M.K., Paraskeva, C., Willson, J.K., Kaz, A.M., Kroh, E.M., Allen, A., Fritz, B.R., Markowitz, S.D \& Tewari, M.(2008). Epigenetic silencing of the intronic microRNA hsa-miR-342 and its host gene EVL in colorectal cancer. Oncogene ,27: 3880-3888.

Guo, Y., Yuan, F., Deng, H., Wang, H.F., Jin, X.L., \& Xiao, J.C.(2011). Paranuclear dot-like immunostaining for CD99: a unique staining pattern for diagnosing solidpseudopapillary neoplasm of the pancreas. Am J Surg Pathol, 35(6):799-806.

Gupta, A., Inaba, S., Wong, O.K., Fang, G.,\& Liu, J. (2003). Breast cancer-specific gene 1 interacts with the mitotic checkpoint kinase BubR1. Oncogene, 22: 7593-7599.

Hamada, S. \& Shimosegawa, T. (2011). Biomarkers of Pancreatic Cancer. Pancreatology, 11(suppl 2):14-19.

Hamaguchi, T., Iizuka, N., Tsunedomi, R., Hamamoto, Y., Miyamoto, T., Iida, M., Tokuhisa, Y., Sakamoto, K., Takashima, M., Tamesa, T., \& Oka, M. (2008). Glycolysis module activated by hypoxiainducible factor 1alpha is related to the aggressive phenotype of hepatocellular carcinoma. Int J Oncol, 33: 725-731.

Handra-Luca, A., Hong, S.M., Walter, K., Wolfgang, C., Hruban, R., \& Goggins, M. (2011). Tumour epithelial vimentin expression and outcome of pancreatic ductal adenocarcinomas. Br J Cancer, 104(8):1296-302.

Harsha, H.C., Kandasamy, K., Ranganathan, P., Rani, S., Ramabadran, S., Gollapudi, S., Balakrishnan, L., Dwivedi, S.B., Telikicherla, D., Selvan, L.D., Goel, R., Mathivanan, S., Marimuthu, A., Kashyap, M., Vizza, R.F., Mayer, R.J., Decaprio, J.A., Srivastava, S., Hanash, S.M., Hruban, R.H., \& Pandey, A. (2009). A compendium of potential biomarkers of pancreatic cancer. PLoS Med, 6(4):e1000046.

He, L., Thomson, J.M., Hemann, M.T., Hernando-Monge, E., Mu, D.,Goodson, S., Powers, S., Cordon-Cardo, C., Lowe, S.W., Hannon, G.J., \& Hammond, S.M.(2005). A microRNA polycistron as a potential human oncogene. Nature, 435: 828-833.

He, P., Naka, T., Serada, S., Fujimoto, M., Tanaka, T., Hashimoto, S., Shima, Y., Yamadori, T., Suzuki, H., Hirashima, T., Matsui, K., Shiono, H., Okumura, M., Nishida, T.,Tachibana, I., Norioka, N., Norioka, S., \& Kawase, I. (2007). Proteomics-based Identification of alpha-enolase as a tumor antigen in non-small lung cancer.Cancer Sci, 98: 1234-1240

He, X.Y., Liu, B.Y., Yao, W.Y., Zhao, X.J., Zheng, Z., Li, J.F., Yu, B.Q., \& Yuan, Y.Z. (2011). Serum DJ-1 as a diagnostic marker and prognostic factor for pancreatic cancer. $J$ Dig Dis, 12(2):131-7.

Heidemann, J., Binion, D.G., Domschke, W., \& Kucharzik, T. (2006). Antiangiogenic therapy in human gastrointestinal malignancies. Gut, 55:1497-1511.

Hermann, P.C., Huber, S.L., Herrler, T., Aicher, A., Ellwart, J.W., Guba, M., Bruns, C.J., \& Heeschen, C. (2007). Distinct populations of cancer stem cells determine tumor 
growth and metastatic activity in human pancreatic cancer. Cell Stem Cell, 1(3):313323.

Hibi, T., Mori, T., Fukuma, M., Yamazaki, K., \& Hashiguchi, A. (2009). Synucleingamma is closely involved in perineural invasion and distant metastasis in mouse models and is a novel prognostic factor in pancreatic cancer. Clin Cancer Res, 15: 28642871.

Hilton, J. (1984). Role of aldehyde dehydrogenase in cyclophosphamide-resistantL1210 leukemia. Cancer Res, 44(11):5156-5160.

Huang, E.H., Hynes, M.J., Zhang, T., Ginestier, C., Dontu, G., Appelman, H., Fields, J.Z., Wicha, M.S., \& Boman, B.M. (2009). Aldehyde dehydrogenase 1 is a marker for normal and malignant human colonic stem cells (SC) and tracks SC overpopulation during colon tumorigenesis. Cancer Res, 69(8):3382-3389.

Huang, H., Dong, X.,\& Kang, M.X.(2010). Novel blood biomarkers of pancreatic cancerassociated diabetes mellitus identified by peripheral blood-based gene expression profiles. Am J Gastroenterol, 105:1661-1669.

Ito, S., Honma, T., Ishida, K., Wada, N., Sasaoka, S., Hosoda, M., \& Nohno, T. (2007). Differential expression of the human alpha-enolase gene in oral epithelium and squamous cell carcinoma. Cancer Sci, 98: 499-505.

Jenuwein, T., \& Allis, C.D. ( 2001). "Translating the histone code". Science ,293 (5532): 107480.

Jia, T., Liu, Y.E., Liu, J., \& Shi, Y.E. (1999). Stimulation of breast cancer invasion and metastasis by synuclein gamma. Cancer Res , 59: 742-747.

Jiang, F., Qiu, Q., Khanna, A., Todd, N.W., Deepak, J., Xing, L., Wang, H., Liu, Z., Su, Y., \& Stass, S.A. (2009). Aldehyde dehydrogenase 1 is a tumor stem cellassociated marker in lung cancer. Mol Cancer Res , 7(3):330-338.

Jiang, N., Meng, Y., Zhang, S., Mensah-Osman, E., \& Sheng, S. (2002). Maspin sensitizes breast carcinoma cells to induced apoptosis. Oncogene, 21:4089-4098.

Kahlert, C., Bergmann, F., Beck, J., Welsch, T., Mogler, C., Herpel, E., Dutta, S., Niemietz, T., Koch, M., \& Weitz, J. (2011). Low expression of aldehyde deyhdrogenase 1A1 (ALDH1A1) is a prognostic marker for poor survival in pancreatic cancer .BMC Cancer, 27;11:275.

Kashima, K., Ohike, N., Mukai, S., Sato, M., Takahashi, M., \& Morohoshi, T.(2008). Expression of the tumor suppressor gene maspin and its significance in intraductal papillary mucinous neoplasms of the pancreas. Hepatobiliary Pancreat. Dis. Int, 7 (1) 86-90.

Katayama, M., Nakano, H., Ishiuchi, A., Wu, W., Oshima, R., Sakurai, J., Nishikawa, H., Yamaguchi, S., \& Otsubo, T. (2006). Protein pattern difference in the colon cancer cell lines examined by two-dimensional differential in-gel electrophoresis and mass spectrometry. Surg Today, 36: 1085-1093.

Kong, W., Yang, H., He, L., Zhao, J.J., Coppola, D., Dalton, W.S., \& Cheng, J.Q. (2008). MicroRNA-155 is regulated by the transforming growth factor beta/Smad pathway and contributes to epithelial cell plasticity by targeting RhoA. Mol Cell Biol, 28: 6773-6784.

Kroep, J.R., Loves, W.J.P., Wilt, C.L., Alvarez, E., Talianidis, I., Boven, E., Braakhuis, B.J., van Groeningen, C.J., Pinedo, H.M., \& Peters, G.J. (2002). Pretreatment 
deoxycytidine kinase levels predict in vivo gemcitabine sensitivity. Mol Cancer Ther, 1:371-376.

Lehmann, U., Hasemeier, B., Christgen, M., Muller, M., Romermann, D., Langer, F., \& Kreipe, H. (2008). Epigenetic inactivation of microRNA gene hsa-mir-9-1 in human breast cancer. J Pathol , 214:17-24.

Lei, W., Hai-Lin, L., Ya, L., \& Ping Y. (2011). Proteomic analysis of pancreatic intraepithelial neoplasia and pancreatic carcinoma in rat models. World J Gastroenterol, 17(11): 1434-1441.

Li, A., Omura, N., Hong, S.M., Vincent, A., Walter, K., Griffith, M., Borges, M.,\& Goggins, M.(2010). Pancreatic cancers epigenetically silence SIP1and hypomethylate and overexpress miR-200a/200b in association with elevated circulating miR-200a and miR-200b levels.Cancer Res, 70: 5226-5237.

Li, C., Heidt, D.G., Dalerba, P., Burant, C.F., Zhang, L., Adsay, V., Wicha, M., Clarke, M.F., Simeone, D.M.(2007). Identification of pancreatic cancer stem cells. Cancer Res, 67(3):1030-1037.

Li, D., Yan, D., Tang, H., Zhou, C., Fan, J., Li, S., Wang, X., Xia, J., Huang, F., Qiu, G., \& Peng, Z. (2009). IMP3 is a novel prognostic marker that correlates with colon cancer progression and pathogenesis. Ann Surg Oncol, 16(12):3499-506.

Li, Z., Sclabas, G.M., Peng, B., Hess, K.R., \& Abbruzzese, J.L. (2004). Overexpression of synuclein-gamma in pancreatic adenocarcinoma. Cancer, 101: 58-65.

Liang, J.J., Kimchi, E.T., Staveley-O'Carroll, K.F. \& Tan, D. (2009) Diagnostic and prognostic biomarkers in pancreatic carcinoma. Int J Clin Exp Pathol, 2:1-10

Locker, G.Y., Hamilton, S., Harris, J., Jessup, J.M., Kemeny, N., Macdonald, J.S., Somerfield, M.R., Hayes, D.F., Bast, R.C. Jr.; ASCO (2006) ASCO update of recommendations for the use of tumor markers in gastrointestinal cancer. J Clin Oncol, 24:5313-5327.

Matsuo, Y. \& Kamitani, T. (2010) Parkinson's disease-related protein, alpha-synuclein, in malignant melanoma. PLoS One, 5(5):e1048.

Mesarosova, A., Hrivnakova, A.\& Babusikova, O. (1993) Acute myeloid leukemia:correlation between purine metabolism enzyme activities and membrane immunophenotype. Neoplasma, 40: 341-345.

Metzler, M., Wilda, M., Busch, K., Viehmann, S. \& Borkhardt, A.(2004) High expression of precursor microRNA-155/BIC RNA in children with Burkitt lymphoma. Genes Chromosomes Cancer, 39: 167-169.

Mikuriya, K., Kuramitsu, Y., Ryozawa, S., Fujimoto, M., Mori, S., Oka, M., Hamano, K., Okita, K., Sakaida, I. \& Nakamura, K. (2007) Expression of glycolytic enzymes is increased in pancreatic cancerous tissues as evidenced by proteomic profiling by two-dimensional electrophoresis and liquid chromatography-mass spectrometry/mass spectrometry. Int J Oncol, 30: 849-855.

Mitchell, P.S., Parkin, R.K., Kroh, E.M., Fritz, B.R., Wyman, S.K., Pogosova-Agadjanyan, E.L., Peterson, A., Noteboom, J., O'Briant, K.C., Allen, A., Lin, D.W., Urban, N., Drescher, C.W., Knudsen, B.S., Stirewalt, D.L., Gentleman, R., Vessella, R.L., Nelson, P.S., Martin, D.B. \&Tewari, M. (2008) Circulating microRNAs as stable blood-based markers for cancer detection. Proc Natl Acad Sci USA; 105: 1051310518. 
Miyazawa, Y., Uekita, T., Hiraoka, N., Fujii, S., Kosuge, T., Kanai, Y., Nojima, Y. \& Sakai, R.(2010) CUB domain-containing protein 1, a prognostic factor for human pancreatic cancers, promotes cell migration and extracellular matrix degradation. Cancer Res, 70: 5136- 5146.

Mo, J.S., Jung, J., Yoon, J.H., Hong, J.A. \& Kim, M.Y. (2010)DJ-1 modulates the p38 mitogenactivated protein kinase pathway through physical interaction with apoptosis signal-regulating kinase 1. J Cell Biochem., 110(1):229-37.

Morgan, J., Hoekstra, A.V., Chapman-Davis, E., Hardt, J.L. \& Kim, J.J. (2009). Synucleingamma (SNCG) may be a novel prognostic biomarker in uterine papillary serous carcinoma. Gynecol Oncol, 114: 293-298.

Morimoto, K., Kim, S.J., Tanei, T., Shimazu, K., Tanji, Y., Taguchi, T., Tamaki, Y., Terada, N. \& Noguchi, S. (2009). Stem cell marker aldehyde dehydrogenase 1-positive breast cancers are characterized by negative estrogen receptor, positive human epidermal growth factor receptor type 2, and high Ki67 expression. Cancer Sci, 100(6):10621068.

Morris, K.V., Chan, S.W., Jacobsen, S.E. \& Looney, D.J. (2004). Small interfering RNAinduced transcriptional gene silencing in human cells. Science, 305:1289-1292.

Nakahira, S., Nakamori, S., Tsujie, M., Takahashi, Y., Okami, J., Yoshioka, S., Yamasaki, M., Marubashi, S., Takemasa, I., Miyamoto, A., Takeda, Y., Nagano, H., Dono, K., Umeshita, K., Sakon, M. \& Monden, M. (2006). Involvement of ribonucleotide reductase M1 subunit overexpression in gemcitabine resistance of human pancreatic cancer. Int J Cancer., 120(6):1355-1363.

Nakano Y, Tanno S, Koizumi K, Nishikawa T, Nakamura K, Minoguchi M, Izawa, T Mizukami, Y., Okumura, T. \& Kohgo, Y. (2007) Gemcitabine chemoresistance and molecular markers associated with gemcitabine transport and metabolism in human pancreatic cancer cells. Br J Cancer 2007, 96:457-463

Niedergethmann, M., Hildenbrand, R., Wolf, G., Verbeke, C.S., Richter, A. \& Post, S. (2000). Angiogenesis and cathepsin expression are prognostic factors in pancreatic adenocarcinoma after curative resection. Int. J. Pancreatol. 28:31-39.

Ohuchida, K., Mizumoto, K., Egami, T., Yamaguchi, H., Fujii, K., Konomi, H., Nagai, E., Yamaguchi, K., Tsuneyoshi, M.\& Tanaka, M. (2006). S100P is an early developmental marker of pancreatic carcinogenesis. Clin Cancer Res, 12:5411-5416.

Okami, J., Simeone, D.M. \& Logsdon, C.D. (2004). Silencing of the hypoxia-inducible cell death protein BNIP3 in pancreatic cancer. Cancer Res., Aug 1;64(15):5338-46

Omura N, Li CP, Li A, Hong SM, Walter K, Jimeno A, Hidalgo M and Goggins M. (2008) Genome wide profiling of methylated promoters in pancreatic adenocarcinoma. Cancer Biol Ther;7:1146-1156.

Ozdemir, N.O., Türk, N.S. \& Düzcan, E. (2011). IMP3 expression in urothelial carcinomas of the urinary bladder. Turk Patoloji Derg., 27(1):31-7.

Polymeropoulos, M.H., Lavedan, C., Leroy, E., Ide, S.E. \& Dehejia, A. (1997). Mutation in the alpha-synuclein gene identified in families with Parkinson's disease. Science, 276: 2045-2047.

Prasad,A.S. \& Kucuk O. (2002). Zinc in Cancer Prevention. Cancer Metastasis Reviews, 21(3-4): 291-295.

Rachagani, S., Kumar, S. \& Batra, S.K. (2010). MicroRNA in pancreatic cancer: pathological, diagnostic and therapeutic implications. Cancer Lett, 292: 8-16. 
Rasheed, Z.A., Yang, J., Wang, Q., Kowalski, J., Freed, I., Murter, C., Hong, S.M., Koorstra, J.B., Rajeshkumar, N.V. \& He, X. (2010). Prognostic significance of tumorigenic cells with mesenchymal features in pancreatic adenocarcinoma. J Natl Cancer Inst 102(5):340-351.

Rebours, V., Levy, P., Mosnier, J.F., Scoazec, J.Y. \& Soubeyrand, M.S. (2010) Pathology analysis reveals that dysplastic pancreatic ductal lesions are frequent in patients with hereditary pancreatitis. Clin Gastroenterol Hepatol. 8(2):206-12.

Roberts, A.S., Campa, M.J., Gottlin, E.B., Jiang, C., Owzar, K., Kindler, H.L., Venook, A.P., Goldberg, R.M., O'Reilly, E.M. \& Patz, E.F. (2011). Identification of potential prognostic biomarkers in patients with untreated, advanced pancreatic cancer from a phase 3 trial (cancer and leukemia group B 80303). Cancer, early on-line.

Roberts, E.L., Newton, R.P. \& Axford, A.T. (2004). Plasma purine nucleoside phosphorylase in cancer patients. Clin Chim Acta, 344: 109-114.

Rocchi, A., Manara, M.C., Sciandra, M., Zambelli, D., Nardi, F., Nicoletti, G., Garofalo, C., Meschini, S., Astolfi A., Colombo, M.P., Lessnick, S.L., Picci, P. \& Scotlandi, K. (2010). CD99 inhibits neural differentiation of human Ewing sarcoma cells and thereby contributes to oncogenesis. J Clin Invest., 120(3):668-80.

Rohloff, J., Zinke, J., Schoppmeyer, K., Tannapfel, A., Witzigmann, H. \& Mossner, J. (2002). Heparanase expression is a prognostic indicator for postoperative survival in pancreatic adenocarcinoma. Br. J. Cancer, 22:1270-1275.

Rosenfeld, J.A., Wang, Z., Schones, D.E., Zhao, K., DeSalle, R. \& Zhang, M.Q. (2009). Determination of enriched histone modifications in non-genic portions of the human genome. BMC Genomics, 10: 143.

Rosty, C. \& Goggins, M. (2002). Early detection of pancreatic carcinoma. Hematol Oncol Clin North Am, 16:37-52.

Sato, N., Fukushima, N., Maehara, N., Matsubayashi, H., Koopmann, J., Su, G.H., Hruban, R.H., Goggins \& M. (2003). SPARC/osteonectin is a frequent target for aberrant methylation in pancreatic adenocarcinoma and a mediator of tumor-stromal interactions. Oncogene. 22(32):5021-30.

Sato, N., Maitra, A., Fukushima, N., van Heek, N.T., Matsubayashi, H., Iacobuzio-Donahue, C.A., Rosty, C. \& Goggins, M. (2003). Frequent hypomethylation of multiple genes overexpressed in pancreatic ductal adenocarcinoma. Cancer Res., 63(14):4158-66.

Sato, N., Matsubayashi, H., Abe, T., Fukushima, N. \& Goggins, M. (2005). Epigenetic downregulation of CDKN1C/p57KIP2 in pancreatic ductal neoplasms identified by gene expression profiling. Clin Cancer Res., 11(13):4681-8.

Sato, N., Parker, A.R., Fukushima, N., Miyagi, Y., Iacobuzio-Donahue, C.A., Eshleman, J.R., Goggins, M. (2005). Epigenetic inactivation of TFPI-2 as a common mechanism associated with growth and invasion of pancreatic ductal adenocarcinoma. Oncogene., 24(5):850-8.

Schutte, M., Hruban, R.H., Geradts, J., Maynard, R., Hilgers, W., Rabindran, S.K., Moskaluk, C.A., Hahn, S.A., Schwarte-Waldhoff, I., Schmiegel, W., Baylin, S.B., Kern, S.E. \& Herman, J.G. (1997). Abrogation of the Rb/p16 tumor-suppressive pathway in virtually all pancreatic carcinomas. Cancer Res; 57:3126-3130.

Sebastiani, V., Ricci, F., Rubio-Viquiera, B., Kulesza, P., Yeo, C.J., Hidalgo, M., Klein, A., Laheru, D. \& Iacobuzio-Donahue, C.A. (2006). Immunohistochemical and genetic 
evaluation of deoxycytidine kinase in pancreatic cancer: relationship to molecular mechanisms of gemcitabine resistance and survival. Clin Cancer Res, 12:2492-2497.

Shen, J., Person, M.D., Zhu, J., Abbruzzese, J.L. \& Li, D. (2004). Protein expression profiles in pancreatic adenocarcinoma compared with normal pancreatic tissue and tissue affected by pancreatitis as detected by two-dimensional gel electrophoresis and mass spectrometry. Cancer Res, 64: 9018-9026.

Shimizu, H., Horii, A., Sunamura, M., Motoi, F., Egawa, S., Unno, M., Fukushige, S. Identification of epigenetically silenced genes in human pancreatic cancer by a novel method "microarray coupled with methyl-CpG targeted transcriptional activation" (MeTA-array) (2011) .Biochem Biophys Res Commun., early on line.

Singleton, A.B., Farrer, M., Johnson, J., Singleton, A., \& Hague, S. (2003) alpha- Synuclein locus triplication causes Parkinson's disease. Science, 302: 841.

Sood, P., Krek, A., Zavolan, M., Macino, G. \& Rajewsky, N. (2006). Cell type-specific signatures of microRNAs on target mRNA expression. Proc Natl Acad Sci USA, 103: 2746-2751.

Sparmann, A. \& van Lohuizen, M. (2006). Polycomb silencers control cell fate, development and cancer. Nat Rev Cancer.6:846-856.

Strahl, B.D.\& Allis, C.D. (2000). The language of covalent histone modifications. Nature 403 (6765): 41-5.

Sugimoto, M., Wong, D.T., Hirayama, A, Soga, T. \& Tomita, M. (2010) Capillary electrophoresis mass spectrometry-based saliva metabolomics identified oral, breast and pancreatic cancer specific profiles. Metabolomics; 6: 78-95.

Szafranska, A.E., Doleshal, M., Edmunds, H.S., Gordon, S., Luttges, J., Munding, J.B., Barth, R.J.Jr., Gutmann, E.J., Suriawinata, A.A., Marc Pipas, J., Tannapfel, A., Korc, M., Hahn, S.A., Labourier, E. \& Tsongalis, G.J. (2008). Analysis of microRNAs in pancreatic fine needle aspirates can classify benign and malignant tissues. Clin Chem. 54: 1716-1724.

Takayama, R., Nakagawa, H., Sawaki, A. Takayama R, Nakagawa H, Sawaki A, Mizuno N, Kawai H, Tajika M, Yatabe Y, Matsuo K, Uehara R, Ono K, Nakamura Y, \&Yamao $\mathrm{K}$ (2010). Serum tumor antigen REG4 as a diagnostic biomarker in pancreatic ductal adenocarcinoma. J Gastroenterol , 45, 52-59

Tanase C.P., Neagu, M., Albulescu, R., Hinescu, M.E.(2010). Advances in pancreatic cancer detection. Adv Clin Chem., 51:145-80.

Tănase, C.P., Raducan, E., Dima, S. O., Albulescu, L., Alina, I., Marius, P., Cruceru, L. M., Codorean, E., Neagu, T.M. \& Popescu I. (2008). Assessment of soluble angiogenic markers in pancreatic cancer. Biomarkers in Medicine, 2(5):447-455.

Tobita, K., Kijima, H., Dowaki, S., Oida, Y., Kashiwagi, H. \& Ishii, M. (2002). Thrombospondin-1 expression as a prognostic predictor of pancreatic ductal carcinoma, Int. J. Oncol., 21, 1189-1195

Toll, A.D., Witkiewicz,A.K. \& Bibbo, M. (2009). Expression of K homology domain containing protein (KOC) in pancreatic cytology with corresponding histology, Acta Cytol., 53, (2), 123-129

Ueki, T, Toyota, M., Skinner, H., Walter, K.M., Yeo, C.J., Issa, J.P., Hruban, R.H. \& Goggins, M. (2001). Identification and characterization of differentially methylated CpG islands in pancreatic carcinoma. Cancer Res., 61(23), 8540-8546. 
van den Bemd, G.J., Krijgsveld. J, Luider. T.M., van Rijswijk, A.L., Demmers, J.A. \& Jenster, G. (2006). Mass spectrometric identificationof human prostate cancer-derived proteins in serum of xenograft-bearing mice. Mol Cell Proteomics, 5,1830-1839.

van Duijn CM, Dekker MC, Bonifati V, Galjaard RJ, Houwing-Duistermaat JJ, Snijders PJ, Testers L, Breedveld GJ, Horstink M, Sandkuijl LA, van Swieten JC, Oostra BA \& Heutink P. (2001) Park7, a novel locus for autosomal recessive early-onset parkinsonism, on chromosome 1p36. Am J Hum Genet, 69, 629-634,

Vareed, S.K., Bhat, V.B., Thompson, C., Vasu, V.T., Fermin, D., Choi, H., Creighton, C.J., Gayatri, S., Lan, L., Putluri, N., Thangjam, G.S., Kaur, P., Shabahang, M., Giri, J.G., Nesvizhskii, A.I., Asea, A.A., Cashikar, A.G., Rao, A., McLoughlin, J. \& Sreekumar, A. (2011). Metabolites of purine nucleoside phosphorylase (NP) in serum have the potential to delineate pancreatic adenocarcinoma. PLoS One., 23, 6(3),e17177.

Vincent, A., Ducourouble, M.P. \& Van Seuningen, I. (2008). Epigenetic regulation of the human mucin gene MUC4 in epithelial cancer cell lines involves both DNA methylation and histone modifications mediated by DNA methyltransferases and histone deacetylases. Faseb J. 22, 3035-3045.

Vire, E., Brenner, C., Deplus, R., Blanchon, L., Fraga, M., Didelot, C., Morey, L., Van Eynde, A., Bernard, D., Vanderwinden, J.M., Bollen, M., Esteller, M., Di Croce, L., de Launoit, Y. \& Fuks, F. (2006). The Polycomb group protein EZH2 directly controls DNA methylation. Nature. , 439, 871-874.

Volinia, S., Calin, G.A., Liu, C.G., Ambs, S., Cimmino, A., Petrocca, F., Visone, R., Iorio, M., Roldo, C., Ferracin, M., Prueitt, R.L., Yanaihara, N., Lanza, G., Scarpa, A., Vecchione, A., Negrini, M., Harris, C.C. \& Croce, C.M. (2006). A microRNA expression signature of human solid tumors defines cancer gene targets. Proc Natl Acad Sci U S A. 103(7), 2257-2261.

Wachter, D.L., Schlabrakowski, A., Hoegel, J., Kristiansen, G., Hartmann, A. \& Riener, M.O. (2011). Diagnostic value of immunohistochemical IMP3 expression in core needle biopsies of pancreatic ductal adenocarcinoma. Am J Surg Pathol., 35(6), 873-877.

Walter, O., Prasad, M., Lu, S., Quinlan, R.M., Edmiston, K.L., \& Khan, A. I. (2009). MP3 is a novel biomarker for triple negative invasive mammary carcinoma associated with a more aggressive phenotype. Hum Pathol. , 40(11), 1528-1533

Woodward, W.A. \& Sulman E.P.(2008). Cancer stem cells: markers or biomarkers? Cancer and Metastasis Reviews, 27(3): 459-470.

Yamada, N., Nishida, Y., Tsutsumida, H., Hamada, T., Goto, M., Higashi, M., Nomoto, M. \& Yonezawa, S. (2008) MUC1 expression is regulated by DNA methylation and histone H3 lysine 9 modification in cancer cells. Cancer Res, ,68:2708-2716

Yanaihara, N., Caplen, N., Bowman, E., Seike, M., Kumamoto, K., Yi, M., Stephens, R.M., Okamoto, A., Yokota, J., Tanaka, T., Calin, G.A., Liu, C.G., Croce, C.M. \& Harris, C.C. (2006).Unique microRNA molecular profiles in lung cancer diagnosis and prognosis. Cancer Cell., 9, 189-198

Ye, Q., Feng, B., Peng, Y.F., Chen, X.H., Cai, Q., Yu, B.Q., Li, L.H., Qiu, M.Y., Liu, B.Y. \& Zheng, M.H. (2009). Expression of gammasynuclein in colorectal cancer tissues and its role on colorectal cancer cell line HCT116. World J Gastroenterol., 15: 50355043 . 
Yin, Q., Wang, X., McBride, J., Fewell, C. \& Flemington, E. (2008). B-cell receptor activation induces BIC/miR-155 expression through a conserved AP-1 element. J Biol Chem, 283, 2654-2662

Yoshida, A., Rzhetsky, A., Hsu, L.C. \&Chang, C. (1998). Human aldehyde dehydrogenase gene family. Eur J Biochem , 251(3), 549-557

Zhang, L., Farrell, J.J., Zhou, H., Elashoff, D., Akin, D., Park, N.H., Chia, D., Wong, D.T.(2010). Salivary transcriptomic biomarkers for detection of resectable pancreatic cancer. Gastroenterology, 138:949-957.

Zhao, J., Chang, A.C., Li ,C., Shedden, K.A., Thomas DG, Misek, D.E., Manoharan, A.P., Giordano, T.J., Beer, D.G., Lubman, D.M. (2007). Comparative proteomics analysis of Barrett metaplasia and esophageal adenocarcinoma using two-dimensional liquid mass mapping. Mol Cell Proteomics, 6, 987-999 


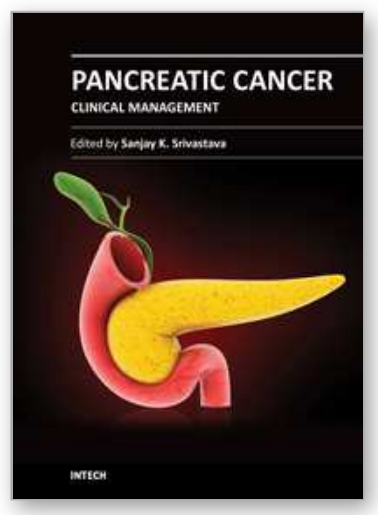

\author{
Pancreatic Cancer - Clinical Management \\ Edited by Prof. Sanjay Srivastava
}

ISBN 978-953-51-0394-3

Hard cover, 312 pages

Publisher InTech

Published online 28, March, 2012

Published in print edition March, 2012

This book covers pancreatic cancer risk factors, treatment and clinical procedures. It provides an outline of pancreatic cancer genetic risk factors, biomarkers and systems biology for the better understanding of disease. As pancreatic cancer suffers from lack of early diagnosis or prognosis markers, this book encompasses stem cell and genetic makers to identify the disease in early stages. The book uncovers the rationale and effectiveness of monotherapy and combination therapy in combating the devastating disease. As immunotherapy is emerging as an attractive approach to cease pancreatic cancer progression, the present book covers various aspects of immunotherapy including innate, adaptive, active, passive and bacterial approaches. Management of anesthesia during surgery and pain after surgery has been discussed. Book also takes the reader through the role of endoscopy and fine needle guided biopsies in diagnosing and observing the disease progression.

\title{
How to reference
}

In order to correctly reference this scholarly work, feel free to copy and paste the following:

Simona O. Dima, Cristiana Tanase, Radu Albulescu, Anca Botezatu and Irinel Popescu (2012). Novel Biomarkers in Pancreatic Cancer, Pancreatic Cancer - Clinical Management, Prof. Sanjay Srivastava (Ed.), ISBN: 978-953-51-0394-3, InTech, Available from: http://www.intechopen.com/books/pancreatic-cancerclinical-management/novel-biomarkers-in-pancreatic-cancer

\section{INTECH}

open science | open minds

\section{InTech Europe}

University Campus STeP Ri

Slavka Krautzeka 83/A

51000 Rijeka, Croatia

Phone: +385 (51) 770447

Fax: +385 (51) 686166

www.intechopen.com

\section{InTech China}

Unit 405, Office Block, Hotel Equatorial Shanghai

No.65, Yan An Road (West), Shanghai, 200040, China 中国上海市延安西路65号上海国际贵都大饭店办公楼 405 单元

Phone: +86-21-62489820

Fax: $+86-21-62489821$ 
(C) 2012 The Author(s). Licensee IntechOpen. This is an open access article distributed under the terms of the Creative Commons Attribution 3.0 License, which permits unrestricted use, distribution, and reproduction in any medium, provided the original work is properly cited. 